\title{
CORONAVIRUS DISEASE 2019 AND CASH FLOW: SEBUAH STUDI KUALITATIF
}

\author{
Yopi Yudha Utama ${ }^{1 *}$, Nadya Arisanti ${ }^{1}$ \\ ${ }^{1}$ Institut Agama Islam Negeri Kediri, Jl. Sunan Ampel No.7 Kediri, Indonesia \\ "Korespondensi: yopiyudhautama@iainkediri.ac.id
}

\begin{abstract}
Coronavirus disease 2019 or known as covid-19 has an impact on various sectors. Besides the health sector, one of the sectors most affected is the economic or financial sector. This can be seen from a number of business actors who close their businesses, including the SME business. This research was conducted to find out how some SMEs managing cash flow to maintain their businesses during the pandemic, especially SME. Therefore, this research was conducted using a case study approach with data collection techniques in the form of interviews with several SMEs. The informants selected in this study came from various business sectors. Among them in the field of bag production, convection, to the food sector. Most of the informants in this study experienced the effects of the co-19 pandemic. Some policies were decided by the informant. These policies such as reimbursement of fixed costs to variable costs, then change the focus of the business, then look for relationships in the immediate area, this policy is taken as a step to keep maintaining the business and amid uncertain conditions.
\end{abstract}

Keywords: Covid-19, Cash Flow, SME, Policy

\begin{abstract}
ABSTRAK
Virus Corona 2019 atau yang dikenal dengan covid-19 memiliki dampak terhadap berbagai sektor. Selain sektor kesehatan, salah satu sektor yang paling terkena dampaknya adalah sektor ekonomi atau keuangan. Hal ini dapat dilihat dari beberapa pelaku usaha yang menutup bisnisnya, tidak terkecuali bisnis UMKM. Penelitian ini dilakukan untuk mengetahui cara beberapa pelaku usaha dalam mengelola arus kasnya untuk mempertahankan usahanya di masa pandemi, khususnya UMKM. Oleh karena itu, penelitian ini dilakukan dengan menggunakan pendekatan studi kasus dengan teknik pengambilan data berupa wawancara kepada beberapa pelaku UMKM. Informan yang dipilih dalam penelitian ini, berasal dari berbagai sektor usaha. Diantaranya pada bidang produksi tas, konveksi, sampai kepada bidang makanan. Sebagian besar informan pada penelitian ini mengalami dampak dari pandemi covid-19. Beberapa kebijakan diputuskan oleh informan tersebut. Kebijakan-kebijakan tersebut seperti penggantian biaya tetap ke biaya variabel, lalu merubah fokus usahanya, kemudian mencari relasi-relasi di area terdekat, Kebijakan ini diambil sebagai langkah untuk tetap mempertahankan usahanya serta ditengah kondisi yang tidak pasti.
\end{abstract}

Kata kunci: Covid-19, Arus Kas, UMKM, Kebijakan 


\section{PENDAHULUAN}

Tahun 2020, mungkin merupakan tahun yang akan memberikan kesan bagi semua kalangan. Baik dari kalangan akademisi, pebisnis, sport athletic dan yang lainnya. Mengapa? Hal ini karena kehadiran makhluk yang berukuran kecil, yang bernama corona virus disease atau yang dikenal dengan virus korona (covid-19). Hadirnya covid-19 ini membuat beberapa orang harus berpikir mengenai tata cara dalam bertahan hidup. Begitu pula dengan para pengusaha. Disamping untuk terus menjaga kesehatannya, dimana mereka tetap harus memperhatikan protokol kesehatan agar terhindar dari covid-19, faktor ekonomi atau faktor keuangan juga menjadi hal yang penting untuk dijaga, baik mereka yang memiliki usaha atau bisnis dalam skala kecil sampai dengan yang memiliki bisnis dalam skala besar.

Pentingnya menjaga faktor ekonomi atau faktor keuangan ini adalah untuk menjaga stabilitas kondisi keuangan di tengah bencana non alam yang tidak pasti kapan akan berakhirnya ini. Apabila faktor keuangan ini tidak dijaga dan tidak direncanakan dengan baik, maka kesulitan keuangan tersebut dapat mengantamnya. Kesulitan keuangan yang terus-menerus terjadi, bisa jadi dapat menyebabkan perusahaan mengalami kebangkrutan. Maka, sebelum mengalami kebangkrutan, perusahaan harus memiliki berbagai strategi untuk keluar dari kondisi kritis ini, atau yang disebut dengan financial distress.

Financial distress merupakan kondisi keuangan perusahaan sebelum terjadinya kebangkrutan (Murtadha et al., 2018; Platt \& Platt, 2002). Beberapa penyebab munculnya kondisi financial distress pada sebuah perusahaan, diantaranya adalah besarnya jumlah hutang, kerugian dalam kegiatan operasional selama beberapa tahun dan kesulitan arus kas (Damodaran, 1997). Dari segi eksternal perusahaan, financial distress juga bisa disebabkan oleh inflasi yang berfluktuasi, suku bunga, gross national product, dan lain sebagainya (Liou \& Smith, 2007).

Bisakah perusahaan mendeteksi kondisi financial distress? Tentu saja bisa. Perusahaan dapat mendeteksi tanda-tanda financial distress diantaranya dengan melakukan analisis keuangan. Salah satunya adalah dengan analisis rasio arus kas (Dwijayanti, 2010; Foster, 1986; Healy \& Palepu, 2008; Kordestani et al., 2011). Lebih lanjut, Dwijayanti (2010) menyatakan jika analisis tersebut dapat digunakan untuk menilai tingkat keberhasilan dalam menjalankan strategi yang telah ditetapkan dan dijalankan, serta mendeteksi kegagalan yang terjadi.

Arus kas merupakan suatu informasi berupa keluar dan masuknya kas dan setara kas entitas atau perusahaan dalam suatu periode, atau dengan kata lain bahwa arus kas merupakan suatu informasi yang memuat pergerakan dari kas perusahaan, baik itu kas masuk maupun kas keluar. Arus kas yang disusun oleh perusahaan, kemudian dinamakan dengan laporan arus kas ini menjadi penting dibuat oleh perusahaan, karena informasi di dalam laporan arus kas tersebut dapat digunakan sebagai faktor atau dasar bagi pihak manajemen untuk membuat suatu keputusan. Menurut Warren et al. (2015:786):

"Laporan arus kas sering kali digunakan oleh para manajer dalam mengevaluasi kegiatan operasi yang telah lalu dan dalam membuat perencanaan aktivitas pendanaan dan investasi di masa depan. Laporan ini juga digunakan oleh investor, kreditur, dan pihak lainnya dalam menilai kemungkinan laba yang diperoleh perusahaan. Selain itu, laporan arus kas merupakan dasar untuk menilai kemampuan perusahaan dalam membayar utang yang jatuh tempo dan membayar dividen"

Arus kas terdiri atas arus kas dari aktivitas operasi, arus kas dari aktivitas investasi, dan arus kas dari aktivitas pendanaan. Arus kas dari kegiatan operasi merupakan arus kas dari aktivitas (suatu transaksi) yang mempengaruhi laba 
perusahaan (Bahri, 2016:153; Warren et al., 2015). Beberapa contoh dari aktivitas operasi ini diantaranya adalah penerimaan kas dari penjualan barang dagang atau pemberian jasa, lalu pengeluaran kas untuk pembelian barang.

Yang kedua, arus kas dari aktivitas atau kegiatan investasi. Arus kas dari aktivitas ini merupakan arus kas yang berhubungan dengan dengan investasi dalam aset tidak lancer. Contohnya seperti penerimaan kas dari penjualan aset tetap, serta penngeluaran kas untuk pembelian aset tetap. Ketiga, arus kas dari aktivitas pendanaan. Aktvitas dalam arus kas ini terkait dengan perubahan komposisi pinjaman maupun ekuitas perusahaan (Warren et al., 2015; Yocelyn \& Christiawan, 2012). Contohnya adalah pelunasan pinjaman, selain itu juga penerbitan surat-surat berharga.

Suatu perusahaan penting untuk mengetahui arus kasnya, karena salah satu fungsinya adalah untuk mengontrol kondisi kas perusahaan tersebut melalui pengambilan keputusan yang didasarkan atas laporan arus kas yang telah dibuat. Tidak hanya untuk perusahaan yang besar saja, namun hal ini juga berlaku bagi UMKM. Yang menarik adalah bagaimana cara UMKM memanajemen atau mengelola arus kasnya pada saat pandemik seperti sekarang ini, agar usaha mereka dapat bertahan dan mungkin kembali stabil seperti sebelum terjadi pandemi. Selain itu, UMKM ini juga dinilai menjadi yang memiliki risiko tinggi oleh bank (Piette \& Zachary, 2015). Penelitian tentang arus kas dan UMKM juga pernah dilakukan oleh Dufour et al. (2018).

Dari paparan yang telah peneliti jelaskan di atas, maka peneliti tertarik untuk melihat cara UMKM dalam menganalisis dan mengelola arus kasnya untuk bertahan di situasi yang tidak pasti, seperti adanya pandemi ini. Tujuan dari penelitian ini adalah untuk mengetahui beberapa cara UMKM dalam menganalisis dan mengelola arus kas usahanya

\section{METODE PENELITIAN}

Penelitian ini merupakan penelitian kualitatif. Penelitian kualitatif merupakan penelitian yang dilakukan untuk menemukan sebuah permasalahan tanpa melibatkan prosedur statistik (Strauss \& Corbin, 2003:4; Utama et al., 2018). Penelitian kualitatif berfokus pada pemahaman terhadap suatu fenomena yang sedang diteliti bukan hanya pada pembaca, peneliti maupun partisipan yang diteliti (Creswell, 2007:3). Alasan peneliti menggunakan penelitian kualitatif adalah karena ingin mengetahui realita-realita sosial (Ahmad et al., 2017; Riharjo, 2011) ataupun dimensi-dmensi dalam dunia sosial, yang didalamnya juga termasuk daily activity (Mason, 2002:1).

Penelitian ini dilakukan dengan menggunakan pendekatan studi kasus. Pemilihan studi kasus adalah karena peneliti ingin mengetahui fenomena yang sedang terjadi ini juga berdampak negatif pada informan penelitian atau justru memberikan dampak yang psoitif. Aziz dalam Ulfatin (2015:55) menjelaskan jika keunggulan studi kasus diantaranya adalah dapat memberikan informasi penting mengenai hubungan antar variabel serta proses-proses yang memerlukan penjelasan dan pemahaman yang lebih luas. Yang kedua, terdapat kesempatan untuk memperoleh wawasan mengenai konsep-konsep dasar manusia, dan melalui penyelidikan yang intensif, peneliti bisa menemukan karakeristik dan hubungan yang (mungkin) tidak diharapkan atau tidak diduga sebelumnya. Studi kasus juga menyajikan data dan temuan yang sangat berguna dalam rangka pengembangan ilmu-ilmu sosial.

Penelitian ini menggunakan teknik wawancara atau interview sebagai metode pengambilan data. Teknik ini digunakan dalam penelitian ini karena untuk memastikan semua responden memahami maksud dan tujuan dari penelitian ini. Hal ini bukan untuk meragukan kemampuan responden dalam menjawab, namun 
lebih ditujukan kepada beliau yang memang tidak memahami dengan baik yang dimaksud dengan arus kas -karena latar belakang pendidikan informan yang tidak sama sekali mempelajari hal tersebut- sehingga jawaban yang diperoleh oleh peneliti menjadi lebih dalam dan sesuai dengan tujuan penelitian. Interview dilakukan kepada enam informan dari beberapa daerah yang memiliki bisnis UMKM. Keenam informan tersebut adalah sebagai berikut:

Tabel 1. Daftar Informan Penelitian

\begin{tabular}{cll}
\hline No & Nama Informan & \multicolumn{1}{c}{ Jenis Usaha } \\
\hline 1 & Ny. A & Bidang Kuliner (Kaki Lima) \\
2 & Tn. E & Tas Anyaman \\
3 & Ny. F & Bidang Kuliner \\
4 & Tn. M & Bidang Kuliner (Café) \\
5 & Tn. V & Toko Kebutuhan Sehari-hari \\
6 & Ny. I & Konveksi
\end{tabular}

Analisis data menggunakan metode dari Cresswell (2016:263). Ia juga berkata jika susunan analisis data yang disajikan olehnya dapat dirubah sesuai dengan praktiknya, sehingga analisis data penelitian ini tidak sama persis dengan yang disajikan oleh Creswell. Berikut analisis data Creswell tersebut:

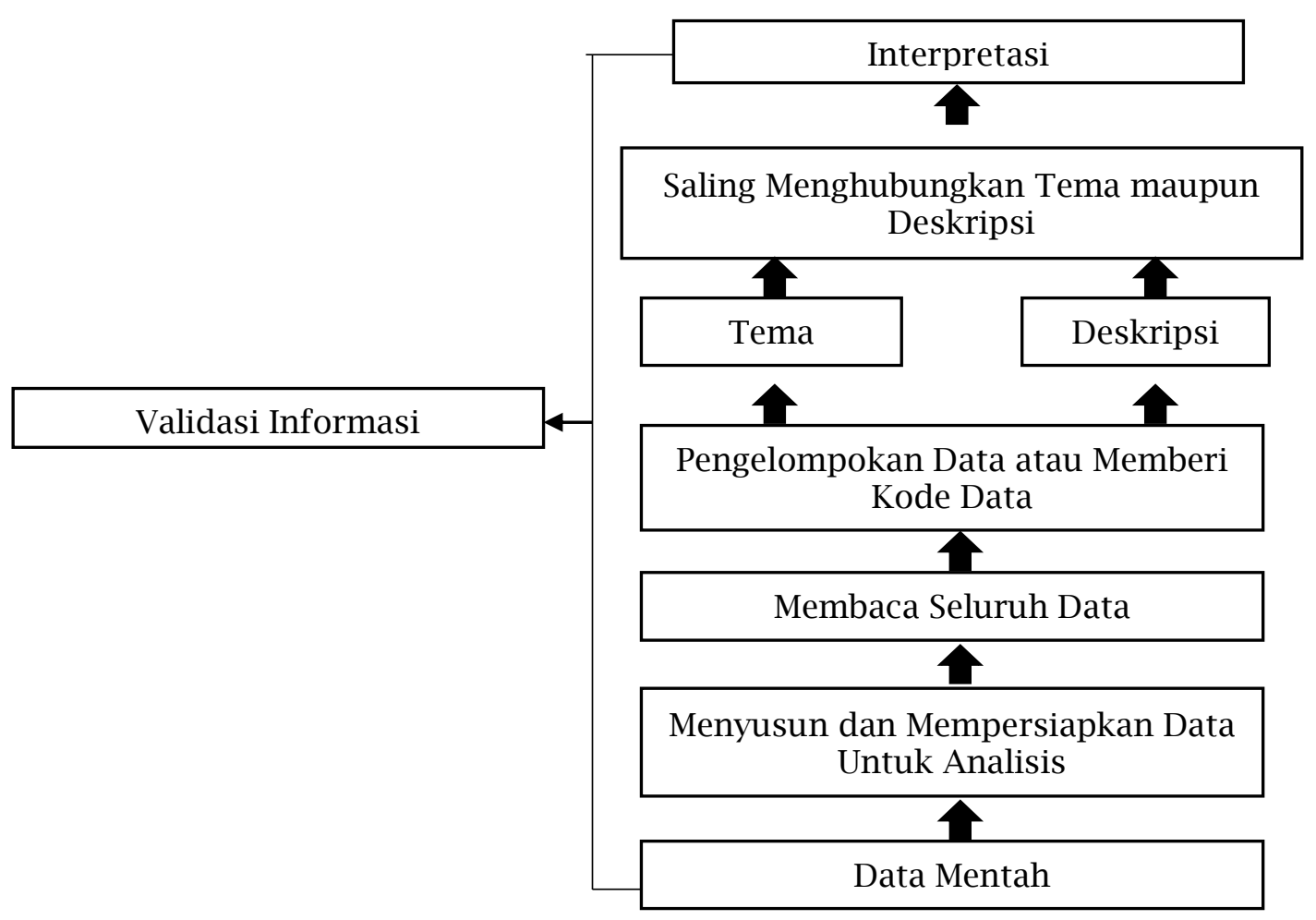

Gambar 1. Model Analisis Cresswell

\section{HASIL DAN PEMBAHASAN}

\section{Dampak Covid-19 Terhadap Usaha}

Hadirnya covid-19 ini memang memberikan dampak kepada hampir seluruh lapisan masyarakat, tidak terkecuali bagi UMKM. Beberapa dari informan dari penelitian ini mengakui jika adanya covid-19 ini memberikan dampak negatif bagi 
usaha mereka. Hal ini seperti yang diungkapkan oleh Ny. K. Beliau yang memiliki usaha di bidang kuliner ini mengakui jika usaha bisnisnya megalami penurunan omset hampir 50\%.

Hal yang senada dengan Ny. A juga disampaikan oleh informan nomer dua atau Tn. E. Beliau yang memiliki usaha di bidang produksi tas anyaman memiliki jawaban sebagai berikut:

"Iya pasti sangat berdampak, apalagi saya yang memiliki usaha yang harus langsung bertemu dengan penjual di pasar untuk menawarkan produksi saya, sedangkan untuk yang sudah biasa order juga tidak bisa ambil karena sektor pasar yang menjadi sasaran utama sedikit lumpuh"

Jawaban yang hampir sama dengan kedua informan sebelumnya, juga diungkapkan oleh Ny. F. Beliau yang memiliki usaha di bidang kuliner, juga terdampak pada salah satu produknya. Meskipun produk yang lainnya mengalami peningkatan yang tajam, namun produknya yang lain, berupa camilan itu produksinya mengalami penurunan yang lebih tajam karena adanya covid-19 ini.

Informan selanjutnya atau Tn. M yang memiliki usaha di bidang kuliner di daerah Sumatera mengatakan jika memang benar kalau adanya wabah covid-19 ini berdampak pada usahanya, namun tidak signinfikan. Jawaban yang hampir sama juga didapat dari informan selanjutnya, yaitu Tn. V. Beliau yang memiliki usaha di bidang jual beli peralatan rumah tangga, mengatakan jika adanya pandemi akibat covid-19 ini tidak terlalu berpengaruh pada usahanya. Tn. V ini memberikan jawaban tersebut, mungkin karena bidang usaha yang dijalankannya, sehingga tidak menurunkan daya beli masyarakat meskipun di tengah pandemi.

Pernyataan yang berbeda justru diberikan oleh Ny. I, dimana usaha beliau bergerak dibidang konveksi. Beliau mengatakan jika dampak dari covid-19 ini justru berdampak positif terhadap usahanya. Hal ini bisa dipahami, karena beliau menyediakan dan menjual masker kain yang memang saat ini menjadi kebutuhan bagi masyarakat. Terlebih lagi terdapat anjuran yang menyatakan jika masyarakat lebih baik memakai masker non medis atau masker kain, sedangkan masker medis hanya untuk para tenaga kerja di bidang kesehatan.

Dari jawaban beberapa informan di atas, diketahui jika mayoritas informan penelitian ini mengalami dampak yang negatif akibat adanya pandemi covid-19 ini, baik yang terkena dampak secara signifikan maupun tidak. Mulai yang terdampak sampai separuh omsetnya terjadi penurunan, produksi barang jadinya benar-benar mengalami "terjun payung", sampai pangsa pasar yang lumpuh. Terutama mereka yang bergerak pada bidang kuliner. Hal ini jika dianalisis lebih lanjut, bidang kuliner menjadi usaha yang rentan terkena dampak adalah karena sistem jual-beli mereka yang langsung berhadapan dengan pembeli. Prosentase jumlah pembeli yang berkurang dari pada kondisi sebelumnya, karena adanya aturan untuk berada di rumah (stay at home) dan juga pemberlakuan PSBB, sehingga hal ini bisa menyebabkan pergerakan masyarakat di luar rumah menjadi terbatas.

\section{Cash Flow Management}

Dalam menjalankan bisnis, seorang pengusaha harus mempersiapkan berbagai strategi dalam menghadapi berbagai risiko yang akan dihadapi. Oleh karena itu, penting bagi pengusaha untuk memiliki manajemen risiko. Selain sebagai cara dalam menghadapi suatu proyek di dalam kondisi yang tidak pasti (Perminova et al., 2008; Sadeh et al., 2010), juga sebagai salah satu penentu keberhasilan suatu proyek (Meyer et al., 2002). Sebagaimana (Junior \& Carvalho, 2013) mengungkapkan jika manajemen risiko itu merupakan hal yang penting untuk keberhasilan proyek apabila diterapkan di dalam perusahaan. 
Salah satu cara dalam mengelola risiko adalah dengan mengelola arus kas dengan baik. Pentingnya mengelola atau menganalisis arus kas dengan baik adalah agar perusahaan dapat terhindar dari kerugian (Milovic \& Miletić, 2014), dan mampu mengambil keputusan yang tepat. Terlebih lagi pada masa pandemi sekarang, analisa atau pengelolaan arus kas yang tepat harus diterapkan dalam setiap langkah agar usaha yang dijalani dapat terus bertahan.

Dalam mengelola arus kasnya, cara yang digunakan oleh Ny. A dalam mempertahankan usahanya agar tetap stabil adalah dengan mengganti biaya tetap menjadi biaya variabel. Misalnya seperti gaji karyawan yang awalnya tetap menjadi dhitung per jam. Sedangkan Tn. E, mengungkapkan jika dalam pengelolaan arus kasnya, beliau mengalihkan fokus biaya operasionalnya kepada bidang lain, seperti pernyataannya berikut ini:

\begin{abstract}
"Kalau di sektor usaha saya lumpuh total karena saya produksi anyaman tas yang biasanya di pakai jualan di pasar, tapi dengan adanya manjemen arus kas saya jadi bisa memanfaatkan uang yang biasanya buat kulak an bahan tas bisa saya buat usaha yang lainnya ternak cupang hias yang notabene tidak perlu bertemu langsung dengan pembeli dan menjualnya via aplikasi instagram dan facebook sehingga bsa buat sedikit pemasukan pengganti usaha yang mampet."
\end{abstract}

Hal yang mirip juga dilakukan oleh Ny. F. Strategi beliau yang salah satu produknya mengalami kenaikan dan produknya yang lain terkena dampak yang signifikan, adalah dengan lebih memfokuskan untuk melakukan pemasaran terhadap produknya yang mendapat keuntungan akibat adanya covid-19 ini. Sementara itu, informain lain yaitu Ny. M, beliau dalam cara mengelola arus kasnya adalah dengan mengontrol pengeluaran sebaik mungkin dan meminimalisir pengeluaran. Sehingga perputaran dana untuk keluarga, usaha, tabungan tetap berjalan, meskipun mungkin tak seperti bulan-bulan sebelumnya.

Jika Tn. E beralih fokus ke bidang lain dan Ny. F lebih fokus kepada produk yang lebih memberi keuntungan, maka Ny. V juga mengalihkan fokusnya dalam hal pencarian agen. Beliau mengatakan jika untuk mengatur arus kasnya agar usahanya tetap stabil adalah dengan mencari agen-agen terdekat untuk memasok bahanbahan yang ada di tokonya. Hal ini dikarenakan adanya kendala waktu barang masuk pada saat adanya kebijakan-kebijakan dalam penanggulangan covid-19. Kendala waktu tersebut dapat mengambat arus persediaannya, sehingga perlu adanya pencarian agen baru yang dapat memasok bahan bakunya sesuai dengan perencanaan yang telah dilakukan.

Pernyataan yang berbeda dari kelima informan sebelumnya, diungkapkan oleh Ny. I. Beliau menyatakan jika manajemen arus kas berjalan seperti biasa, baik sebelum adanya pandemi maupun pada saat pandemi. Pernyataan dari Ny. I menjadi wajar, karena usaha beliau tidak terpengaruh sama sekali dengan adanya pandemi ini, namun justru diuntungkan.

Beberapa cara yang telah dilakukan oleh informan diatas sesuai dengan yang diungkapkan oleh Noor et al. (2012). Noor et al. (2012) mengungkapkan jika ada beberapa cara untuk mengatasi masalah arus kas, diantaranya adalah improving profitability, improving marketing plans, leasing or renting, refinancing, liquidating assets, and changing production plans. Tn. E misalkan, peralihan fokus usaha yang dilakukannya ini merupakan bagian dari changing production plans. Begitu juga dengan yang dilakukan oleh $\mathrm{Ny}$. V dengan mencari supplier pengganti, ini juga merupakan salah satu strategi dalam changing production plans. Dengan memahami risiko keuangan dari mitra dagang utama, pelanggan, dan pemasok adalah pertimbangan yang harus cepat ditentukan di saat-saat seperti ini. Keputusan yang telah diambil dan dilakukan oleh Tn. E dan Ny. V tersebut, mereka 
berharap dapat mempertahankan atau bahkan meningkatkan arus kasnya dan memungkinkan mereka untuk mempertahankan profitabilitas pada saat yang sama.

Tidak hanya pada Tn. E dan Ny. V, changing production plans juga menjadi pertimbangan bagi Ny. F. Apakah Ny. F sebaiknya menghentikan produksi terhadap salah satu produknya yang anjlok tersebut? Untuk sementara waktu, sebaiknya bukan mengentikan produksi tersebut, melainkan adalah dengan mengurangi jumlah produksinya. Hal ini untuk tetap menjaga pangsa pasar dari produk tersebut. Dalam rentang waktu tertentu, maka beliau bisa melakukan analisa lebih lanjut terkait produk yang terkena dampak negatif tersebut, sehingga mampu menghasilkan keputusan yang lebih tepat. Berikutnya, improving marketing plans. Ini merupakan cara yang dilakukan oleh Ny. F. Beliau lebih "menggenjot" pemasaran produk yang terdampak positif akibat pandemi ini. Dengan lebih mengutamakan pemasaran pada salah satu produknya yang terdongkrak naik akibat pandemi ini, maka hal ini dapat mempertahankan kesehatan arus kasnya dan berdampak terhadap kondisi keuangan usaha yang dijalankannya.

Tidak mudah memang bagi mereka untuk mengambil keputusan-keputusan yang cepat dan tepat dalam merespon kondisi yang sekarang. Seperti yang dilakukan oleh Ny. A misalkan, beliau mengganti biaya tetap menjadi biaya variabel (Liu \& Tyagi, 2016). Misalnya seperti gaji karyawan yang awalnya tetap menjadi dihitung per jam. Ada hal yang dilematis dalam pengambilan keputusan pengkonversian biaya tersebut, mengapa? Mengganti gaji tetap menjadi per jam ini berarti pemasukan untuk sumber daya manusianya menjadi berkurang. Apakah ini keputusan yang terbaik? Jawabannya adalah iya, karena karyawan yang berada di lapangan tentu sudah memahami dengan baik kondisi yang terjadi. Dengan pasokan persediaan yang berkurang atau terlambat, jumlah pelanggan yang juga ikut berkurang, namun biaya masih tetap stabil, hal ini tentu berpengaruh pada kondisi keuangan usahanya. Oleh karena itu, untuk menyeimbangkan kondisi tersebut, operasional tetap berjalan lancar, dan win-win solution bagi karyawan dan Ny. A, maka mengganti beberapa biaya tetap menjadi biaya variabel adalah keputusan terbaik saat ini bagi Ny. A.

\section{The Importance of Cash Flow}

Arus kas dalam suatu perusahaan, harus dipantau secara berkala. Hal ini agar perusahaan dapat memperkirakan arus kas di masa depan, menentukan kemampuan perusahaan dalam membayar dividen kepada para pemegang saham, memperlihatkan hubungan laba bersih terhadap perubahan arus kas perusahaan, serta sebagai salah satu indikator untuk mengevaluasi keputusan manajemen (Horngren et al., 2003:845). Maka dari pada itu, apabila perusahaan kurang peduli terhadap pengelolaan arus kas, dapat membuat kondisi perusahaan menjadi tidak terkontrol dengan baik, dan jika hal itu akan dilakukan berulang-ulang, dapat menimbulkan kerugian bagi perusahaan.

Pengelolaan terhadap arus kas tersebut juga dilakukan oleh informan penelitian ini. Informan atas nama Ny. A, menyatakan jika kerugian akan membesar apabila tidak melakukan manajemen arus kas terutama pada kondisi seperti saat ini. Secara tidak langsung, beliau menunjukkan betapa pentingnya pengelolaan arus kas.

Sementara itu, Tn. E mengatakan jika beliau tidak melakukan pengelolaan arus kas, maka bisa jadi beliau tidak memiliki pemasukan atau pendapatan sama sekali, karena tidak adanya modal yang bisa putar agar bisa mendapatkan pemasukan dari usaha yang lain. Beliau juga mengungkapkan jika arus kas ini penting karena untuk membuat perputaran uang yang mendadak seperti keadaan saat ini sehingga tetap mendapatkan pemasukan untuk keberlangsungan hidup. Hal yang hampir senada juga diungkapkan oleh $\mathrm{Ny}$. $\mathrm{M}$, yang mengatakan jika tidak memperdulikan 
pengelolaan arus kas maka keuangan dalam usaha dan juga kebutuhan rumah tangga akan kacau ke depannya dan mungkin dapat mengakibatkan tidak berjalannya perputaran dana untuk bulan selanjutnya. Maka dari itu, beliau mengungkapkan jika arus kas ini penting, sehingga sistem keuangan dalam usaha dan juga keluarga tetap stabil.

Kerugian akibat tidak memperhatikan arus kas juga diungkapkan oleh Ny. M. Beliau menyatakan jika perolehan (pendapatan) toko bisa berkurang, kekurangan stok barang, bahkan kehilangan pelanggan. Dengan begitu arus kas ini beliau anggap penting, salah satunya juga untuk membiayai gaji dari karyawannya agar tetap berjalan. Selanjutnya, pada informan terakhir, yaitu Ny. I, beliau menekankan jika dalam menentukan langkah-langkah yang akan diambil untuk memajukan perusahaan, maka sangat penting untuk memperhatikan arus kas agar mengetahui kondisi keuangan perusahaan.

Dari pernyataan informan diatas maka semuanya memberikan jawaban yang senada, yaitu pentingnya dalam mengelola arus kas. Hasil yang didapatkan dari interview informan penelitian ini sejalan dengan pernyataan yang diungkapkan oleh Omag (2016) yaitu "for the successful performance of business organizations, cash flow is an essential element of financial management process". Dengan sadar akan keberadaan arus kas, maka mereka bisa mengetahui kondisi keuangan usahanya. Hal ini seperti yang dinyatakan oleh Taillard (2012), yaitu laporan arus kas dianggap membantu dalam penentuan likuiditas dan profitabilitas, penilaian aset operasional dan manajemen keuangan.

\section{SIMPULAN}

Adakah manusia bisa yang menduga covid-19 ini menjadi pandemi? Jawabannya adalah kemungkinan tidak ada. Kondisi luar biasa karena adanya pandemi covid-19 seperti sekarang ini, maka para pelaku usaha yang beregerak dalam bidang apapun harus memperhatikan segala aspek terkait dengan usahanya. Baik itu sumber daya manusianya, their supply chain, maupun pemahaman lebih dalam tentang analisis risiko bisnis. Dalam hal ini termasuk pengelolaan tentang arus kas. Di dalam penelitian ini beberapa informan yang terimbas dari pandemi covid-19 ini, mereka harus mengembangkan berbagai rencana maupun strategi dalam pengelolaan arus kasnya. Hal ini dilakukan sebagai respon yang terjadi atas risiko bisnis mereka dan juga sebagai cara untuk tetap "menyehatkan" arus kas mereka. Kebijakan-kebijakan yang mereka ambil dan lakukan juga untuk keberlangsungan hidup dari usaha mereka, terlebih lagi dalam uncertainty condition.

Arus kas ini harus dipantau secara berkala, karena arus kas merupakan salah satu faktor yang menentukan pengambilan keputusan. Selain itu juga dapat digunakan untuk menilai tingkat keberhasilan dalam menjalankan strategi yang telah ditetapkan dan dijalankan, serta mendeteksi kegagalan yang terjadi. Seperti yang dilakukan oleh para informan dalam penelitian ini. Semua informan dalam penelitian ini sepakat akan pentingnya arus kas. Kebijakan-kebijakan dalam pengelolaan arus kas seperti penggantian biaya tetap ke biaya variabel, lalu merubah fokus usahanya, kemudian mencari relasi-relasi di area terdekat dan semacamnya menjadi beberapa pilihan yang dapat diambil.

Untuk para pelaku UMKM yang sekiranya memiliki usaha di bidang kuliner misalkan, yang pada awalnya menjual makanan matang, dengan kondisi sekarang ini mungkin bisa juga membuka makanan mentah atau bahan mentah yang isinya disesuaikan dengan menu masakan pesanan pembeli. Hal ini menjadi salah satu cara bagi pembeli yang merasa khawatir berlebihan. Selanjutnya siapkan berbagai macam strategi, seperti bekerja sama dengan suatu platform gratis dalam 
menjalankn kegiatan bisnisnya dalam menghadapi situasi seperti sekarang ini agar usaha terus berjalan bahkan lebih baik dari pada kondisi sebelumnya.

\section{DAFTAR RUJUKAN}

Ahmad, A., Djamhuri, A., \& Kamayanti, A. (2017). ICU auditors"e understanding of achieving good university governance. The Indonesian Accounting Review, 6(2), 227-238.

Bahri, S. (2016). Pengantar Akuntansi. Andi.

Creswell, J. W. (2007). Qualitative Inquiry \& Reseacrh Design: Choosing Among Five Approaches (2nd ed.). SAGE Publications.

Damodaran, A. (1997). Corporate Finance, Theory and Practice. John Wiley \& Sons.

Dufour, D., Luu, P., \& Teller, P. (2018). The Influence of cash lfow on the speed of adjustment to the optimal capital structure. Research in International Business and Finance, 45, 62-71.

Dwijayanti, S. P. F. (2010). Penyebab, Dampak, dan Prediksi dari Financial Distress serta Solusi untuk Mengatasi Financial Distress. Jurnal Akuntansi Kontemporer, 2(2), 191-205.

Foster, G. (1986). Financial Statement Analysis, 2/e. Pearson Education India.

Healy, P. M., \& Palepu, K. G. (2008). Business analysis valuation: Using financial statements. Cengage Learning.

Horngren, Harrison, Robinson, \& Secokusumo. (2003). Akuntansi Di Indonesia (Vol. 2). Salemba Empat.

Junior, R. R., \& Carvalho, M. M. de. (2013). Understanding the impact of project risk management on project performance: An empirical study. Journal of Technology Management \& Innovation, 8, 6.

Kordestani, G., Bakhtiari, M., \& Biglari, V. (2011). Ability of combinations of cash flow components to predict financial distress. Business: Theory and Practice, 12(3), 277-285.

Liou, D.-K., \& Smith, M. (2007). Macroeconomic Variables and Financial Distress. Journal of Accounting, Business \& Management, 14, 17-31.

Liu, Y., \& Tyagi, R. K. (2016). Outsourcing to convert fixed costs into variable costs: A competitive analysis. International Journal of Research in Marketing, 34(1), 252-264.

Mason, J. (2002). Qualitative Researching (2nd ed.). SAGE Publications Ltd.

Meyer, A. De, Loch, C. H., \& Pich, M. T. (2002). Managing Project Uncertainty: From Variation to Chaos. MIT Sloan Manage-Ment Review, 43(2), 60.

Milovic, M., \& Miletić, D. (2014). Cash Flow Management In The Contemporary Ways of Conducting Business In The Republic of Serbia. Finiz: Business Finance, 101104.

Murtadha, M. A., Arfan, M., \& Saputra, M. (2018). Factors Influencing Financial Distress and Its Impact on Company Values of the Sub-Sectors Firms in Indonesian. Journal of Accounting Research, Organization and Economics, 1(2), 191-204.

Noor, M. I., Nour, A., Musa, S., \& Zorqan, S. (2012). The role of cash flow in explaining the change in company liquidity. Journal of Advanced Social Research, 2(4), 231-243.

Omag, A. (2016). Cash flows from financing activities. Evidence from the automotive industry. International Journal of Academic Research in Accounting, Finance 
and Management Sciences, 6(1), 115-122.

Perminova, O., Gustafsson, M., \& Wikström, K. (2008). Defining uncertainty in projects-a new perspective. International Journal of Project Management, 26(1), 73-79.

Piette, C., \& Zachary, M.-D. (2015). Sensitivity to the crisis of SME financing in Belgium. Economic Review, iii, 31-45.

Platt, H. D., \& Platt, M. B. (2002). Predicting corporate financial distress: reflections on choice-based sample bias. Journal of Economics and Finance, 26(2), 184-199.

Riharjo, I. B. (2011). Memahami Paradigma Penelitian Non-Positivisme Dan Implikasinya Dalam Penelitian Akuntansi. Jurnal Akuntansi, Manajemen Bisnis Dan Sektor Publik (JAMBSP), 8(1), 128-146.

Sadeh, A., Dvir, D., \& Shenhar, A. J. (2010). Defense vs. civilian projects: The effect of project type on performance. PICMET 2010 TECHNOLOGY MANAGEMENT FOR GLOBAL ECONOMIC GROWTH, 1-10.

Strauss, A., \& Corbin, J. (2003). Dasar-dasar Penelitian Kualitatif. Pustaka Pelajar.

Taillard, M. (2012). Corporate Finance for Dummies. John Wiley and Sons.

Ulfatin, N. (2015). Metode Penelitian Kualitatif Di Bidang Pendidikan: Teori Dan Aplikasinya. MNC Publishing.

Utama, Y. Y., Sukoharsono, E. G., \& Baridwan, Z. (2018). The Urgency in Implementing the Accounting Sustainability of Spiritual Dimension in the Sustainability of Company. Journal of Accounting and Business Education, 3(1), 105-122.

Warren, C. S., Reeve, J. M., Duchac, J. E., \& Djakman, C. D. (2015). Pengantar Akuntansi: Adaptasi Indonesia. Salemba Empat.

Yocelyn, A., \& Christiawan, Y. J. (2012). Analisis Pengaruh Perubahan Arus Kas dan Laba Akuntansi Terhadap Return Saham pada Perusahaan Berkapitalisasi Besar. Jurnal Akuntansi Dan Keuangan, 14(2), 81-90. 